\title{
The personality of krystal weedon in J.K Rowling's the casual vacancy : a psychoanalysis study
}

\author{
Sutrisno ${ }^{\mathrm{a}, 1, *}$ \\ ${ }^{a}$ Litelature English Departement Ahmad Dahlan \\ ${ }^{1}$ selvie@com.uad.ac.id*; \\ * corresponding author
}

\begin{tabular}{|c|c|}
\hline & ABSTRACT \\
\hline $\begin{array}{l}\text { Article history } \\
\text { Received } 01-09-2020 \\
\text { Revised } 11-11-2020 \\
\text { Accepted } 13-11-2020 \\
\\
\text { Keywords } \\
\text { The Casual Vacancy } \\
\text { Krystal Weedon }\end{array}$ & $\begin{array}{l}\text { The writer discuss about the personality of the main character, Krystal } \\
\text { Weedon, in The Casual Vacancy. The writer focuses on the personality } \\
\text { of Krystal Weedon by using psychoanalysis approach. In this research, } \\
\text { the writer used qualitative research method. Quality refers to the what, } \\
\text { how, when, and where of a thing its essence and ambience. This novel } \\
\text { described a unique personality of Krystal Weedon as a teenager that has } \\
\text { many problems in her life. By means of the background above, the } \\
\text { writer would like to analyze the novel The Casual Vacancy using } \\
\text { psychoanalysis study to reveal the personality of the main character in } \\
\text { this novel. }\end{array}$ \\
\hline
\end{tabular}

This is an open access article under the CC-BY-SA license.

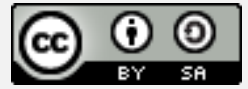

\section{Introduction}

The novel is one form of a literary work. The novel is a story of fiction in the form of writing or words and has intrinsic elements and extrinsic elements. A novel usually tells the story of human life in interacting with the environment and each other. In a novel, the author is trying everything possible to direct the reader to the reality of life figures through the stories contained in the novel. Novel is viewed psychological phenomena such as from main character personality that in a novel.

The Casual Vacancy is the one of literary work in Modern Era. The original published in hardcover by Little, Brown and Company, September 2012. This novel is an adult novel that telling the casual vacancy in Local Council. The different novel from J.K Rowling before, Harry Potter (Rowling, 2007).

The novel told about politics and the real social life. The Casual Vacancy had a lot of different characters with different personalities. The story begun from the death of main character "Barry Fairbrother", a city council in Pangford, which caused vacancy of chair in the city. The other character that made writer interested is Krystal Weedon, a teenager who came from bad family. Her mother is a drug and free sex addict. When Krystal was child, she used to saw her mother did it in their house. Her childhood was not easy too, she also got sexual deviation from her friends in school and the people kept silent about it because they believed that 'like mother like daughter'. Kristal hated it absolutely, so she used to skip her class and broke the school rules. Barry Fairbrother was Krystal's teacher. When Krystal was with him, she showed good attitude. It was totally different attitude when she was with people who were bullying her. In one occasion, Krystal joined the rowing team in her school and became a leader. Under her leadership, her team won several competitions (Abrams, 1997).

This novel described a unique personality of Krystal Weedon as a teenager that has many problems in her life. By means of the background above, the writer would like to analyze the novel 
The Casual Vacancy using psychoanalysis study to reveal the personality of the main character in this novel.

\section{Theorotocal Framework}

As far as the writer concerns, the writer finds out some research on The Casual Vacancy. The writer finds the research from thesis of The Casual Vacancy and the writer shows some feedback from societies about The Casual Vacancy by J.K Rowling.

First, it is a thesis written by Nurliana Fitria (2014) student of Faculty of Culture Science Mulawarman University who has written thesis "The Portrayal of Patriarchal Oppression towards the Female Characters in J.K. Rowling's The Casual Vacancy: A Reflective Post Feminist Critics". Her thesis concentrated in the patriarchal system abuse or oppression towards the female characters in J.K. Rowling's The Casual Vacancy (Nurliana \& Chaira, 2017). On her thesis, she finds five symbols of patriarchy which is found in the novel.

Second, the research from Literary Criticism Journal of Imma Rachayu and Laura Aprilia the student from University of Dehasen Bengkulu. The title of their thesis is "An Analysis of psychological impact on Juvenile delinquency in J.K Rowling's The Casual Vacancy (2012)". They concentrated to find out about how the influence of the Id, Ego and Super Ego of the teenage characters in the novel and to know that there is a kind of juvenile delinquency in the novel The Casual Vacancy (2012) by using Sigmund Freud theory. The writers ultimately conclude that the dominant juvenile delinquency, are the use of cigarettes and drugs. Adolescent mental condition is always influenced by the presence of the id, ego and super-ego as it had been by Sigmund Freud describe through the theory of psychoanalysis (Shaheen, Chan, \& Gaynor, 2016).

Third, research thesis is from Nopitasari student of Muhammadiyah University Surakarta. Her thesis is "Exclusivism Reflected in J.K Rowling The Casual Vacancy Novel (2012): A Sociological Perspective". Her thesis is focused to clear that in The Casual Vacancy novel, J.K Rowling delivers message that exclusives can lead to exploitation and oppression. From the sociological analysis, it is apparent that there is a strong relation between this novel and the social reality in England in early twenty first century (Nopitasari, 2017) .

In this research, the writer used qualitative research method. Quality refers to the what, how, when, and where of a thing its essence and ambience. Qualitative research thus refers to the meanings, concepts, definitions, characteristics, metaphors, symbols, and descriptions of things. In contrast, quantitative research refers to counts and measures of things (Berg, Tymoczko, \& Stryer, 2002). This research is about collecting data.

The primary source of the novel "The Casual Vacancy" is in the form of words, dialogue, phrases and sentences. Then, the data was taken from biography document of the author, other writings by the author, historical text, movie and video about the subject and various studies about the subject by some scholars. The other data will be taken from the book that related with the research and searching sources from internet access : (1) Method of Collecting Data (2) Method of Analyzing Data (Hjerm, 2004).

\section{Results and Discussion}

As mentioned in the previous chapter, the aim of this study is to analyze the personality of the main character, Krystal Weedon in J. K. Rowling's The Casual Vacancy. The results of this study are presented in this chapter and the explanations below are based on the question of the research as stated in the Chapter I.

This novel described a unique personality of Kristal Weedon as a teenager that has many problems in her life. Krystal Weedon had a psychological conflict within herself. She experience of a variety of psychological problems. In the novel, the author describes on how Krystal's personality struggled in her adolescence. Krystal is a strong-willed teenager but she easily change, her decision depends on the environment and the people she faces and meet. In other word, Krystal's personality is shaped by her environment. 
Based on this finding research, the writer would like to analyze the Krystal's personality from good and bad perspective whom she did in her social life. J. K. Rowling describes Krystal's personality and behaviour through the dialogs among the characters in the text form of the novel. The writer examines the narration and the dialogue of the character to analyze it.

The writer uses the theory of Sigmund Freud's Psychoanalysis to analyze Krystal Weedon's personality. This major theoretical approach is to understanding the personality include trait, psychoanalytic, social learning, and humanistic theories (Rachayu \& Banat, 2020).

According to Sigmund Freud's psychoanalytic, there are three different parts of the personality. They are the id, the ego and the super ego. The Id, which operates on the pleasure principle, wants immediate gratification of instates needs. The Ego, which operates on the reality principle, tries to find acceptable ways to gratify the id. Then, the Super Ego represents parental and societal values (Freud, 1949). In this undergraduate thesis, the writer will analyze the personality of Krystal Weedon from The Id, The Ego and The Superego perspective.

Krystal Weedon is a 16 years old girl and student of Winterdown Senior High School. She lives in The Fields with her 4 year old brother, Robbie and their drug addicted prostitute mother, Terri. They live in dirty slum where every house's wall is filled with the obscene scrawled-word. It is shown what kind of people who lives in that dirty place.

"Krystal Weedon is no advert for that woman's mothering skills," said Miles. (p.288)

"Krystal's trying her damnedest to hold her family together," said Kay. She loves her little brother very much; she's terrified he'll be taken away." (p.288)

"I wouldn't trust Krystal Weedon to look after a boiling egg," said Miles. (p.288)

"Krystal bullied our daughter Lexie," said Samantha, "so we've seen a different side of her to the one I'm sure she shows you". (p.288)

"Look, we all know Krystal's had a rough deal," said Miles, "nobody's denying that. It's the drug-addled mother I've got an issue with." (p.288)

From the conversations above, the writer finds out that Krystal gets bad estimation from the society because she comes from a drug addict mother. It was a bad signature that given by the people in her society towards her.

However, Krystal also has a good side in her personality. As mentioned before that since children, Krystal lives with a drug addict mother, Terri, so she has to look after her younger brother, Robbie who is still 4 years old. In this case, Krystal replaces Terri as a mother to Robbie. That makes Krystal should act as a parent to her little brother. Sometimes when her mother was in bad condition because of the drug effect, Krystal also looks after her mother and all of the house necessity, as illustrated in the following quotation:

"A pile of refuse was heaped against the front wall: carrier bags bulging with filth, jumbled together with old clothes and unbagged, soiled nappies. Bits of the rubbish had tumbled or been scattered over the scrubby patch of lawn, but the bulk of it remained piled beneath one of the two downstairs windows. A bald old tire sat in the middle of the lawn; it had been shifted sometime recently, because a foot away there was a flattened yellowish-brown circle of dead grass. After ringing the doorbell, Kay noticed a used condom glistening in the grass beside her feet, like the gossamer cocoon of some huge grub." (p.81)

"We've known Krystal since she was five: she was in our son's class at primary school," Tessa said. "She's had an awful life, really." (p.398)

Absolutely," said Kay. "It's astounding she's as sweet as she is, actually." (p.398)

"The daughter's sixteen," said Una. "She mostly takes care of Robbie." (p.101)

Krystal Weedon faces the hardship life. It changes Krystal's personality from a cheerful teenager into matured girl. Some people around her knew how hard Krystal's life is. But, they not give support to Krystal to make her life is better. Based on the conversations above, the writer finds that 
Krystal gets a good perspective from people in her society when she is doing this job, to look after her family.

Krystal is angry and uncontrollable when knowing that Obbo gives more heroins to her mother. After that, she is quarrelled with her mother. She does not want to lose Robbie for the second time. The uncontrolled anger is a form of her way in showing that she is strong and able to face her problems. She could stand and bear it. She does not want others to see her slumped or sadness. To express her feeling, she only could release her anger by doing something bad. It can be seen in the following quotation.

"Krystal flung herself violently off the chair, away from her mother. She was surprised to feel warm liquid flowing down her cheeks, and thought confusedly of blood, but it was tears, only tears, clear and shining on her fingertips when she wiped them away." (p.138)

Krystal's mood changes drastically changed due to the promises made by Kay as a social worker to Krystal. Krystal is excited because she thinks this week is a week of fun. Change was evident in her family. As illustrated in the quote below:

"Terri was adhering to the Bellchapel regime again, and Krystal was making sure that Robbie went to nursery. His buttom had mostly healed over. The social worker seemed as pleased as her sort ever did. Krystal had been to school every day too, though she had not attended either her Monday or her Wednesday morning guidance sessions with Tessa. She did not know why. Sometimes you got out of the habit." (p.318)

From the quotation above, the writer finds that Krystal's personalities can be changed. It is depending on how her emotional and the condition of her environment. If she is happy, then she will show a positive personality, conversely-vice versa.

The same as with Krystal's attitude in her home, in the school, Krystal also has a bad and good personality. Krystal also has some bad personality in her school. There are many reasons that makes she does that bad attitude. It influenced by the situation, condition and people who are surrounding her. Krystal is often hookied from the school. She is doing this when she feels angry, bored, upsets and uncomfortable. Sometimes she simply goes out from the gate and then comes back again. Krystal has a wishy-washy personality. It makes her doing this attitude.

Krystal's bad behaviour is that she is kleptomania. She steals people's property. She ever stole her counsellor teacher's watch and Nikki's goods box. She neither wore nor sold the things she took.

"Tessa sank into her chair with a low groan, took off her wristwatch, which pinched, and placed it on the desk beside various printed sheets and notes" (p.51)

"Krystal kept hers in a box she had stolen from Nikki's house. Krystal was much given to sneaking things into her pockets that belonged to people she liked. This box was plastic and decorated with roses; a child's jewellery box, really. Tessa's watch was curled up inside it now" (p.133)

"She was also unsettled and guilty about having stolen Tessa Wall's watch. But why had the silly bitch put it there in front of Krystal and closed her eyes? What did she expect?" (p.129)

Actually, Krystal feels guilty towards her action in stealing her counsellor teacher's watch, Tessa Wall, but her ego is ignored it. Her ego is not let her to apologize to her teacher. Finally, her superego becomes a wrong and she blamed her teacher for her carelessness by leaving her watch on the desk. This superego rejected the action which is done by Krystal.

In her school, since she was a child, Krystal was always being abused by her friends. Krystal was bullied by her friends. Krystal used multiple earrings swung from each ear, and the string of her thong was clearly visible above her low-slung tracksuit bottoms. Since she was in elementary school, Krystal's friends had been mocking her name.

"They had jeered at her name, but instead of crying, as most of the little girls would have done, five-years-old Krystal had caught on, cackled and shrieked, "Weed-on! Krystal weed-on!" And she had pulled down her pants in the middle of class and pretended to do it. He retained a vivid memory 
of her bare pink vulva; it was as though Father Christmas had popped up in their midst; and he remembered Miss Oates, bright red in the face, marching Krystal from the room" (p. 32)

From the explanation above, Krystal is did immoral things. Sometimes, she's embarrassing herself in front of her friends, she lets her friends behave immorally against her and she does not rejected at all, even though she does not like that, because since childhood she saw her family doing the same actions towards her.

Moreover, Krystal also has a good personality. For example, she always takes care of her mother and younger brother. She cares with Mr. Barry Fairbrother, because he is very kind to Krystal. She also is a good leader to her school's rowing team. She helps her friends, Andre Prize when he has allergy of peanut in her school. Actually Krystal is a kind person. She just needs everyone to motivate and support her to be a better person.

Krystal was being the leader in the rowing team which chosen Mr. Barry Fairbrother. When facing a race in the final regional competition against St. Anne, they won. Although they were suppressed by the opposing team, Krystal has a unique way of calming the team's oars. As shown in quotation below:

“s'pose your shit smells of roses, does it?" (p.637)

"I beg your pardon?" said their coach. (p.637)

"Jus' askin'," said Krystal sweetly, turning her back to pull off her tracksuit bottoms. (p.637)

The urge to giggle had been too powerful to resist; the Wintersown team snorted with laughter as they changed. Krystal clowned away, and as the St. Anne's crew filled out she mooned them. (p.637)

"Charming," said the last girl to leave. (p.637)

"Thanks a lot," Krystal called after her. "I'll let yer 'ave another look later, if yeh want. I know yeh're all lezzers," she yelled, "stuck in 'ere together with no boys!" (p.637)

From the quotations above, it is shown that Krystal also could speaks with disrespectful line. That is her way to press her fear of the opponents in the race. It was also her way to calm and to reassure her rowing team members that they could also win. Krystal could make her friends laugh so her friends could relax for the race later. She liked it when she could win the rowing game. Krystal's good nature was also cited in the following quotations:

"She was glad and proud to be walking along behind Krystal, and she could tell that the others were too. Something about how Krystal faced the world was protecting them from the effect of the staring eyes and the fluttering bunting, and the building like a palace in the background." (p.638)

"Krystal had won it for them. Krystal had taken away the home ground advantage. Sukhvinder wished that she could be like Krystal: funny and tough; impossible to intimidate; always coming out fighting." (p.638)

By the various explanations above, the writer concludes that Krystal's personality changed faster because of her situation, condition and society. She would be a good person if she meets with a good person, vice versa. Krystal needs more support from her society and family. She needs a motivation to help her to be better. She is not bad girl, she just less attention and direction. She did a wrong thing to show her feeling. She does not want others to see her sadness and hardship in her life.

\section{Conclusion}

Based on the previous discussion, the writer makes a conclusion that the personality of the main character, Krystal Weedon in J. K. Rowling's The Casual Vacancy which describes as a young teenager has been influenced by her social life, in neighbourhood as well as in the school society.

In addition, the personality of Krystal Weedon is also formed by the characteristic, attitude and condition of her family member. For instance, her prostitute and drug addict mother is influenced Krystal to be a wild teenager. Krystal suffers a traumatic childhood. The lost of her older brother 
who is taken by the government because of her mother condition is also makes Krystal becomes affectionate person. She really cares and loves her younger brother, Robbie. She does not want Robbie has been taken by the government like her older brother. She does not want lost her brother anymore. This condition is possessed in changing and developing of Krystal's personality.

In the school society, Krystal often gets bullying from her friends. They are bullying her because she comes from awkward family with prostitute and drug addict mother. They regard Krystal as a whore, just like her mother. It makes Krystal cannot bear it. She is often hookied from the school to avoid them. However, when Mr. Barry Fairbrother comes to her school, coached the girls' rowing team, Krystal attitude is changed. Mr. Fairbrother is not likes other people who always think negative toward Krystal. He never looks bad at Krystal. He could see the positive side which adheres to the Krystal's personality. Even, he chooses Krystal to be the leader of the girls' rowing team. This is effected the change on Krystal's personality. Krystal becomes a good and cheerful girl. She has enthusiasm to go to the school. Moreover, she could bring the victory to her rowing team.

Krystal's personality is being good and bad is depending on her condition, situation, society and people surroundings her. In fact, the writer found that Krystal's bad personality is only appeared to show her strengthen in facing people's bullying and negative assumption toward her and her family. She wanted to show to the people that she could stand and bear it. She is doing this because she does not want people excommunicate her from the society and regarded her as a weak person. However, there are good personalities of Krystal Weedon. She is kind of an affectionate person. She really loves her brother and her mother and puts more attention to them. She does not want to lose them. Krystal is also good in sports. As a matter of fact, she needs people's attention and guidance to be a better person, just like Mr. Fairbrother did.

\section{References}

Abrams, M. H. (1997). The Transformation of English Studies: 1930-1995. Daedalus.

Berg, J., Tymoczko, J., \& Stryer, L. (2002). Biochemistry, 5th edition. In Biochemistry.

Hjerm, M. (2004). Metod. Sociologisk Forskning. https://doi.org/10.6027/9789289335805-5-sv

Nopitasari, E. (2017). Pengaruh Lokasi, Produk, Reputasi, Dan Pelayanan Terhadap Keputusan Mahasiswa Iain Surakarta Menggunakan Bank Syariah. Institut Agama Islam Negeri Surakarta.

Nurliana, \& Chaira, T. M. I. (2017). Pengaruh Pertumbuhan Ekonomi Terhadap Distribusi Pendapatan Di Indonesia. Jurnal Samudra Ekonomi.

Rachayu, I., \& Banat, A. (2020). The Development Of Hypnotherapy Based - Interpersonal Communication Model For Students Suffered From Game Addiction. Journal of Educational Science and Technology (EST). https://doi.org/10.26858/est.v6i1.10707

Rowling, J. (2007). Book 7 - Harry Potter and the Deathly Hallows. Fiction. https://doi.org/10.1353/bcc.2007.0672

Shaheen, S. A., Chan, N. D., \& Gaynor, T. (2016). Casual carpooling in the San Francisco Bay Area: Understanding user characteristics, behaviors, and motivations. Transport Policy. https://doi.org/10.1016/j.tranpol.2016.01.003 